\title{
Antifeedant Effect of Moringa oleifera (L.) Leaf and Seed Extract on Growth and Feeding Activity of Spodoptera litura (Fab.) (Lepidoptera: Noctuidae)
}

\author{
Amelia Tridiptasari ${ }^{1 *}$, Amin Setyo Leksono ${ }^{2}$, Dian Siswanto ${ }^{2}$ \\ ${ }^{1}$ Master Program of Biology, Faculty of Mathematics and Natural Sciences, University of Brawjaya, Malang, Indonesia \\ ${ }^{2}$ Departement of Biology, Faculty of Mathematics and Natural Sciences, University of Brawijaya, Malang, Indonesia
}

\begin{abstract}
This study was conducted to evaluate the effect of Moringa oleifera leaf and seed extract on length, weight, and feeding activity of Spodoptera litura. Leaf and seed were extracted by maceration method in $70 \%$ ethanol. Bioassays were conducted by using five concentrations $(0 \%, 5 \%, 10 \%, 15 \%, 20 \%)$ on 5 larvae by leaf-dip method with 5 times replication. The result showed that leaf and seed of Moringa extract contained alkaloid, flavonoid, and saponin which gave antifeedant effect to growth and feeding activity of larvae. The increased extract concentrations are lead to weight loss and the length shrinkage of larvae. The extracts promoted prolongation of the larval instar. Reduction of food intake of the larva is in line with the concentration increase of extracts. The antifeedant effect also affects time to stop feeding and give mortality of larvae.
\end{abstract}

Keywords: antifeedant, leaf, moringa, seed, S. litura

\section{INTRODUCTION}

Agriculture is one of the largest sectors for the economy in developing countries, including Indonesia. One of the efforts made in improving the quality and quantity of productivity is pest control. Insect pests are known to cause significant damage to crops and affect agricultural productivity because they eat the crops as their food [1].

Insect pests from order Lepidoptera are found throughout the world [2]. Spodoptera litura (Fab.) (Lepidoptera: Noctuidae) which is known attack many types of crop, such as cotton, soybean, tobacco, onion, chili, corn, and rice [6]. The survey showed S. litura was found in 16 regencies in East Java with leaf damage rate above $12.5 \%$ [3]. The $S$. litura has a wide range of host, feeding nearly on 112 species worldwide [4]. It is causing considerable economic loss to many vegetable and fruit crops. Pest control use chemical insecticides has been a fundamental tool for pest control, but leads to serious consequences such as intoxication of people and animals, contamination of water, air, and soil, residues on food, high persistence in the environment, resistance in pest, and impact on beneficial insect [5] or non-target insect, and secondary pests explosion [6]. This impact encourages to use biological control methods

\footnotetext{
* Correspondence address:

Amelia Tridiptasari

Email : atridiptasari@gmail.com

Address : Dept. Biology, University of Brawijaya, Veteran Malang, Malang 65145.
}

without damaging the environment or harming other organisms. The holistic approach towards insect pest management which includes the use of botanicals such as plant products to pest control and combat resistance problem [12]. This is in line with the government program in the effort to protect crops productivity which applies the Integrated Pest Control technique in accordance with Presidential Instruction No 3 of 1998 [7].

Several types of plants have been known to have potential as botanical pesticides because of the content of phytochemical compounds that have an antifeedant impact and mortality on insect pests. Earlier studies have indicated that antifeedant compound derived from leaf, seeds, flowers, fruit, and root of the plants can be used as botanical pesticides to against the growth and metamorphose of the noxious insects [12]. This compound came from processed organ plants into various forms, such as raw materials in the form of flour, extras, or resins which are the result of extracting liquid secondary metabolites from plant parts.

Phytochemicals are a group of non-nutrient compounds that are naturally synthesized by plants. These compounds are in flowers, tubers, leaves, fruit, roots, tree bark, and in the rhizome. Phytochemicals act as a defensive mechanism for the plants against disease and many external attacks. Phytochemicals are the results of primary or secondary metabolites of plants [8]. These substances include saponins, tannins, alkaloids, flavonoids, and terpenoids. Moringa is a plant that contains active compounds alkaloids, 
flavonoids, saponins, steroids, and tannins [8]. In the study $[9,10]$ Moringa seeds proved to be larvacidal against Anopheles stephensi and Moringa flowers had a larvacidal effect on the Aedes aegypti. Moringa seed extract contains high concentrations of flavonoids, and leaves contain flavonoids, alkaloids, saponins, and tannins [8]. Based on the results of previous studies, Moringa oleifera can be used as a candidate for botanical pesticides, especially in $S$. litura. The purpose of this study was to determine the antifeedant effect of $M$. oleifera leaf and seed extract on growth and feeding activity of S. litura larvae.

\section{MATERIAL AND METHOD}

\section{The culture of $S$. litura}

Spodoptera litura larvae were obtained from the Research Institute for Sweeteners and Fiber Plants (BALITTAS), Malang. Larvae are collected at the second instar stage and are ready for use at the third instar. The larvae are stored in jam bottles ( 5 larvae each bottle) that have been given mustard leaves as feed. The bottle is closed using a cloth. Feed is replaced every day and dirt cleaned using a brush.

\section{Extraction of Moringa Leaf and Seed}

Moringa leaves and seeds are powdered into simplicia. Total 500 grams of simplicia was extracted with $3750 \mathrm{~mL}$ of ethanol using the maceration method. The maceration vessel is closed and left for 3-4 days, protected from direct sunlight. The immersion was stirred in several times, so the diffusion process of dissolved compounds in ethanol more effective [11]. The immersion was filtered using a cloth. The resulting filtrate was then evaporated using a rotary evaporator [13] to evaporate the solvent. The resulting extracts were then stored in the refrigerator $\left(\leq 4^{\circ} \mathrm{C}\right)$ until ready to used. The extract use for bioassay studies in five concentrations (0\%,5\%,10\%, 15\%, and 20\%).

\section{Total Phytochemical Assay for Moringa Leaf and Seed}

The tested phytochemicals were flavonoids [29], alkaloids, and saponins [30]. The total phytochemical content test was carried out by the spectrophotometric method. Each extract was tested in duplicate.

\section{Bioassay of extract}

The third instar S. litura larvae are exposed for 1-2 hours before testing. Each of the concentrations of the extracts was prepared and put in a small basin container. Mustard leaves that are still fresh and not contaminated with chemical pesticides are dipped in each concentration for \pm 10 seconds. Testing is done by the deep-in method and then placed on a tray to be air dried. The leaves are inserted into all jam bottles which contain S. litura larvae [6]. Each concentration used 5 larval and repeated 5 times. The total number of $S$. litura larvae used was 250 individuals.

\section{Observation of Antifeedant Effect}

The development of larvae was observed starting from the 3rd instar larvae to the instar 5. Observation variables included the length, weight, feed residue, development time, observed at each turn of the larval instar stage, and the stopped eat time which was observed at 4,8 , and 12 hours after the application (HAA).

\section{RESULTS AND DISCUSSION}

The result of the total phytochemical compound of leaves and seeds showed that all samples positive contained flavonoids, alkaloids, and saponins (Table 1). In each extract, it was known that the content of flavonoids and alkaloid was relatively higher compared to saponins. These results are in line with the study [14], which showed that flavonoid content (3.46

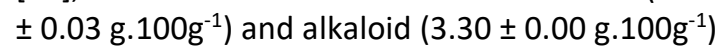
in $M$. oleifera was higher than saponin content

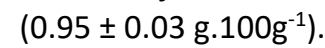

Table 1. The total compound of phytochemical of $M$. oleifera

\begin{tabular}{cccc}
\hline \multirow{2}{*}{ Extract } & \multicolumn{3}{c}{ Total $\left(\mathbf{m g . 1 0 0 g}^{-\mathbf{1}}\right)$} \\
\cline { 2 - 4 } & Flavonoid & Alkaloid & Saponin \\
\hline \multirow{2}{*}{ leaf } & 3157.095 & 153.711 & 106.159 \\
& 3205.656 & 154.542 & 108.814 \\
\hline \multirow{2}{*}{ seed } & 2075.002 & 205.134 & 65.553 \\
& 2041.744 & 209.240 & 63.703 \\
\hline
\end{tabular}

The three secondary metabolites gave antifeedant effect to the development of S. litura larvae including length, weight, larval development time, food residue, and time to stop eating. Secondary metabolites in plants have an impact on growth, development, and reduced digestive capacity in insects [15].

Flavonoids, alkaloids, and saponins on Moringa leaves and seeds give significant different to the length of $S$. litura larval on various instars. The increased concentration of Moringa leaf and seed extract declined the mean length of S. litura larvae (Fig. 1). The 3rd instar larva on both treatment significantly different between control (0\%) and with all 
concentrations, except 5\%. The 4th instar and 5th instar were significantly different at all concentration. The shrinkage of larvae lenght is higher in larva treated by Moringa seed extract than the leaf. This is due to the higher alkaloid in Moringa seeds than Moringa leaves. Alkaloids become inhibitors of several metabolisms. Alkaloid inhibits the work of sucrose in the intestine in digestive metabolism and affects the growth of larvae [16].

The treatment of Moringa leaf and seeds extracts also affects the weight of larvae of $S$. litura. The increase of extract concentration in line with losing weight of larvae (Fig. 1). Alkaloids cause lose weight and a decrease in food intake of insects [17]. In the study [18] reported that the alkaloid from $P$. harmala was studied in $S$. greraria and it caused weight loss. Based on the previous research, it was explained that the presence of rapid neurotoxicity symptoms hampered larval feeding activity [17]. The weight of each larval instar growth has decreased which higher in the treated diet of Moringa seed extract. The weight of the 3rd instar larvae with both extracts was not significantly different in 3rd instar and 4th instar between control and 5\% concentration. Alkaloids for insects act as stomach and contact toxic. Alkaloids in the form of salt can be degraded cell membranes in the digestive tract to enter and damage cells.

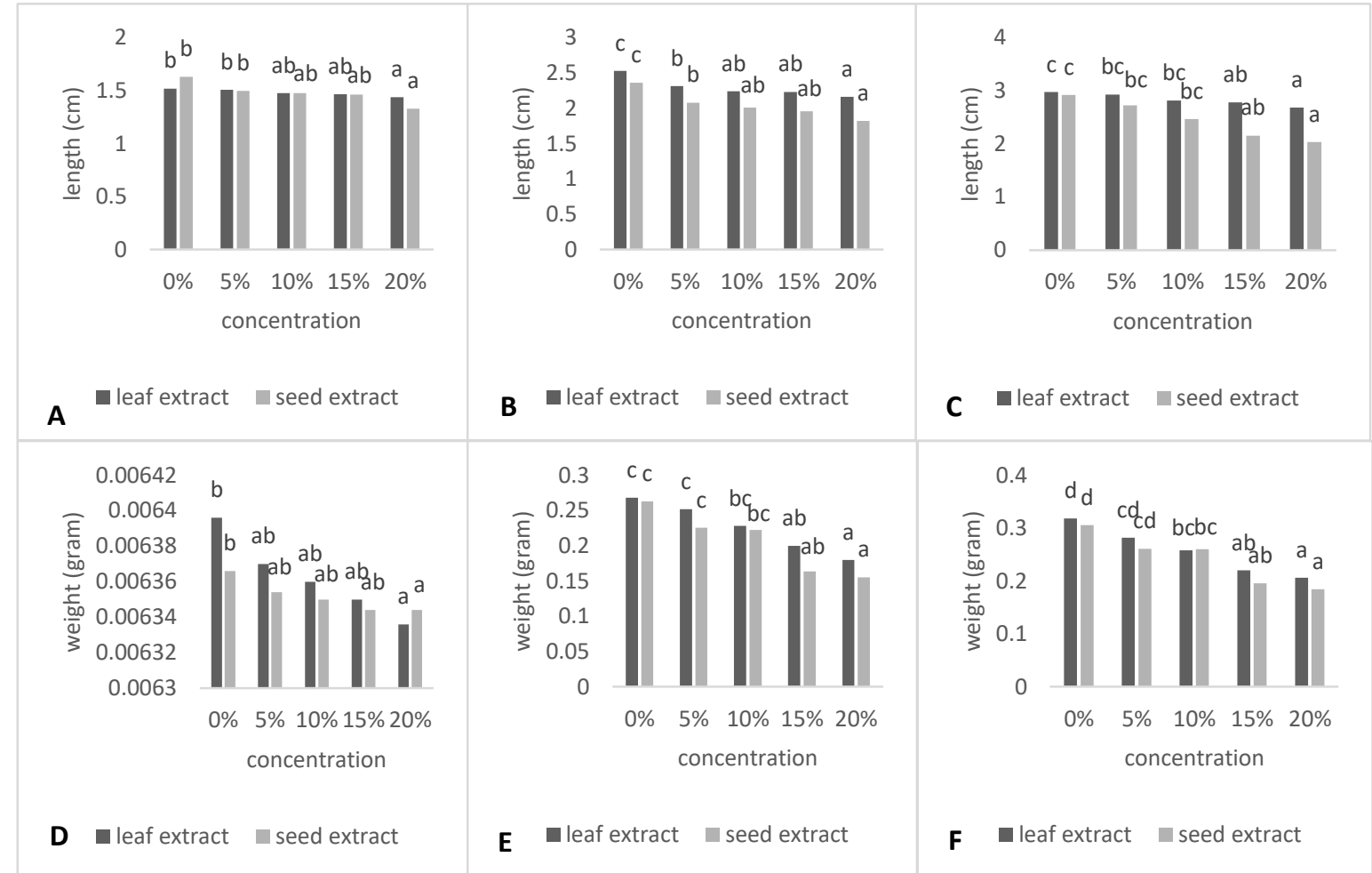

Figure 1. Mean length of $S$. litura on diet treated by moringa extract in 3rd instar (A), 4th instar (B), 5th instar (C); and mean weight of $S$. litura on diet treated by moringa extract in 3rd instar (D), 4th instar (E), 5th instar (F).

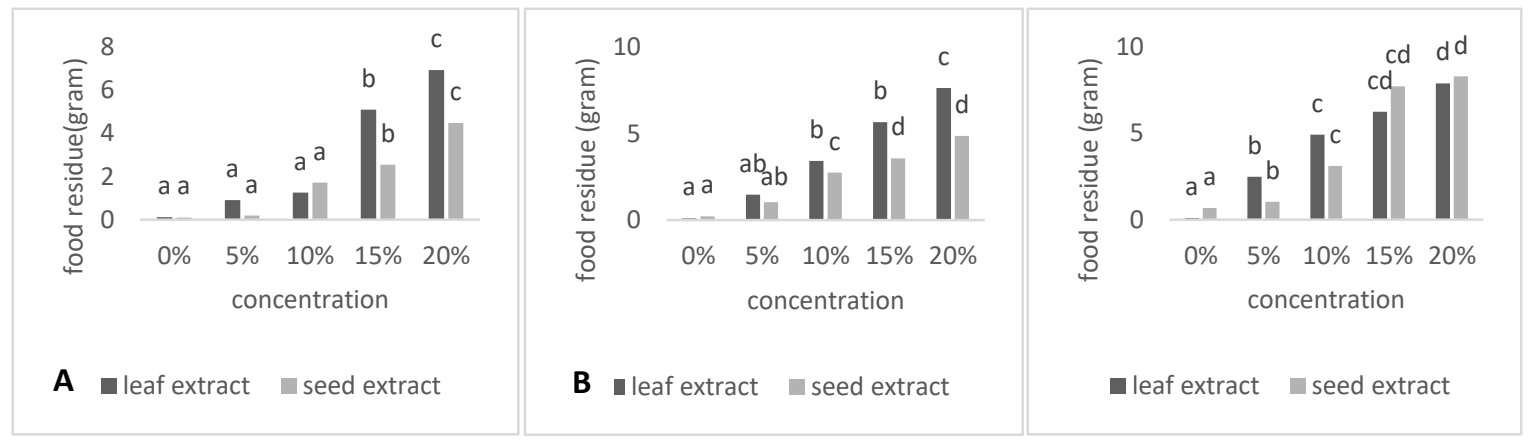

Figure 2. Mean food residue of $S$. litura on diet treated by moringa extract in 3rd instar (A), $4 \operatorname{th}$ instar (B), 5th instar (C) 
These results indicate that alkaloids interfere with neuroendocrine control by inactivating acetylcholinesterase in larvae [19]. Alkaloids from some plants have a similar effect to blocking the acetylcholinesterase enzyme. This enzyme cannot work in the body to continue sending the signal to larval digestive [20]. Higher alkaloid content in Moringa seed extract caused weight loss in larval higher than larvae given Moringa leaf extract.

In addition to alkaloids, flavonoid content also affected the length and weight of larvae. Flavonoids affect molting, reproduction, feeding, and insect behavior, including cutworms [21]. Flavonoids in plants can reduce digestive ability or can even be toxic [22]. This is related to food residue of S. litura larvae (Fig. 2). Food intake in control larvae was higher than the treatment of both extracts. In Figure 3, it can be seen that the higher concentration of the extract reduced the food intake of larvae. Feeding with the addition of leaf extract and seed extract caused a decrease in larval feed residue for each increase in concentration.

Alkaloid, flavonoids, and saponins give antifeedant effect in insects. Antifeedant compounds affect eating behaviour through the direct action of insect taste organs. The insect's reaction was refusing to eat or eating in small amounts. Increased feed residue at each increase in extract concentration because the food is not suitable and stops eating temporarily or permanently. This feeding inhibitory activity is related to the sensitivity of gustatory neurons and thus inhibits insect growth [27].

The activity of inhibiting eating by extracts of Moringa leaves and seeds is also shown by the results of the time to stop eating. In Figure 4, the time to stop eating of $S$. litura after feeding with the addition of Moringa leaf and seed extract increased.

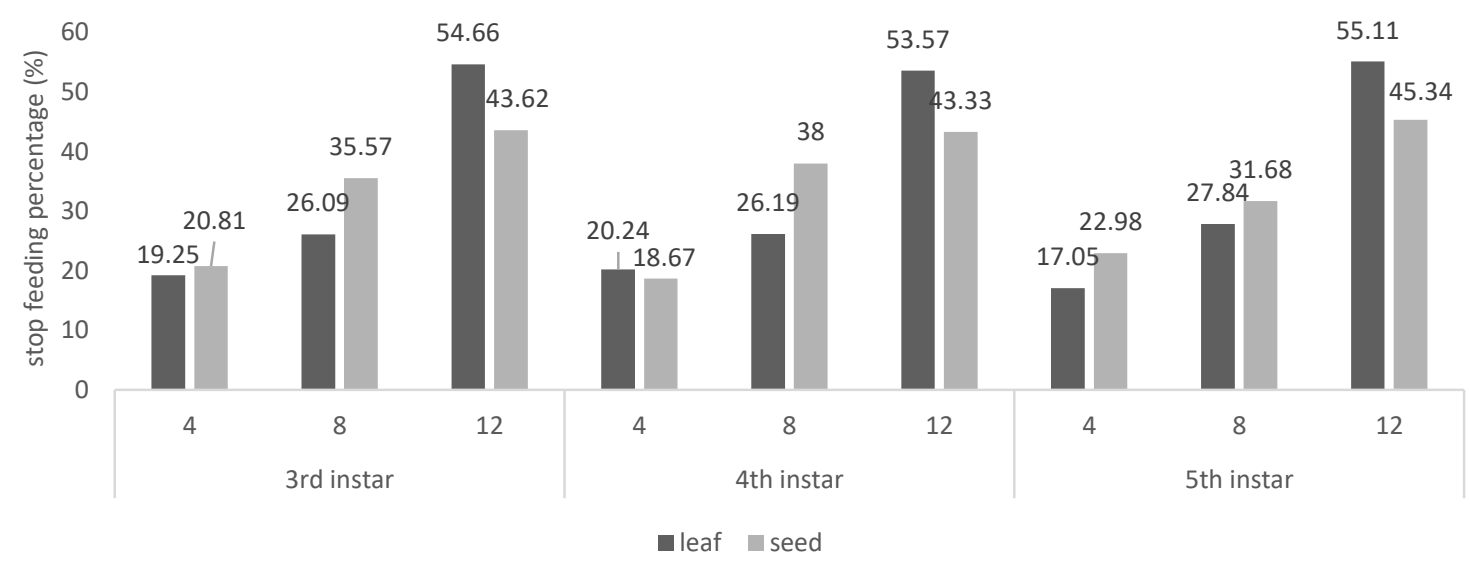

Figure 3. Percentage of stop feeding of $S$. litura on diet treated by moringa extract in 3rd instar (A), 4th instar (B), 5th instar (C) at 4 hours after application (HAA), 8 HAA, and 12 HAA

On the 3rd, 4th, and 5th instar, treatment of Moringa leaf and seeds extract caused the percentage of time to stop feeding at the 4th, 8th and 12 th hours after application (HAA) increased. At 4,8 , and $12 \mathrm{HAA}$, the percentage of time to stop feeding with Moringa leaf extract treatment was higher than the seeds extract on the third and fifth instar. On the fourth instar, the percentage of time to stop eating was higher in Moringa seed extract treatment at 4 and 12 HAA. Leaf and seeds extract containing bioactive substances from secondary metabolites that inhibited larval activity, marked by slow motion, no response to the motion, and stop feeding [6].

The secondary metabolites also affect the duration of development of larvae. In Figure 4, it can be seen that the larval development duration did not differ significantly in the development of the 4th instar larvae in both extracts and 5th instar with the of Moringa leaf extract treatment. Plant secondary metabolites can disturb development, lead to malformations or malfunctions, extend the duration of developmental stages or act as repellents [23]. Diet treatment on larval gives development time prolonged compared to control, although statistically not significantly different. The extent of development time is due to a disruption in the insect hormone development, namely brain hormone $(\mathrm{BH})$, juvenile hormone $(\mathrm{JH})$, and the ecdysone hormone. This disruption caused by saponin in the extracts. 


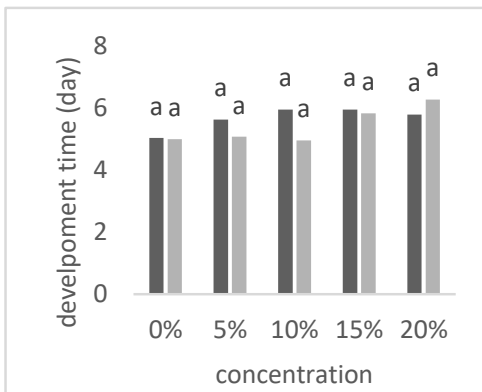

A leaf extract $\square$ seed extract
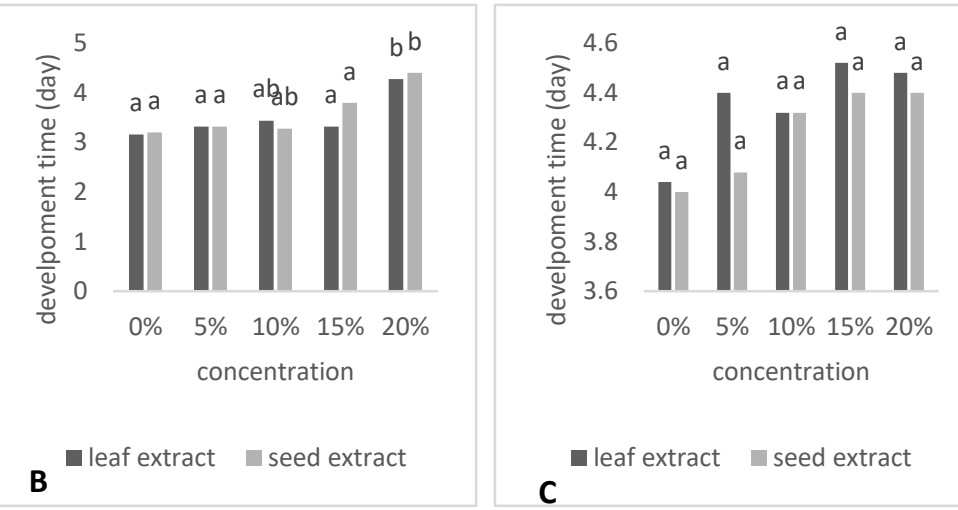

Figure 4. Mean development time of S. litura on diet treated by moringa extract in 3rd instar (A), 4th instar (B), 5th instar (C)

Saponins are terpenoid compounds. The activity of saponins in the insect's body is to bind free sterols in the digestive tract of food. Sterols are substances that function as precursors of the ecdysone hormone [25]. Larvae growth is affected by $\mathrm{JH}$. As long as there is $\mathrm{JH}$, the molting that occurs under the control of ecdysone hormone will only produce an immature stage of larval. If the concentration of $\mathrm{JH}$ is relatively higher compared to the ecdysone hormone, it will stimulate the larvae and prevent the formation of pupae [28]. It was reported that the saponin content of $S$. litura growth resulted in prolongation of the development stage, including at the larval stage [26]. In addition to giving prolongation of the development stage, the secondary metabolites in Moringa leaf and seed also causing mortality to larval. Mortality is characterized by reduced in eating activity and passive movements.

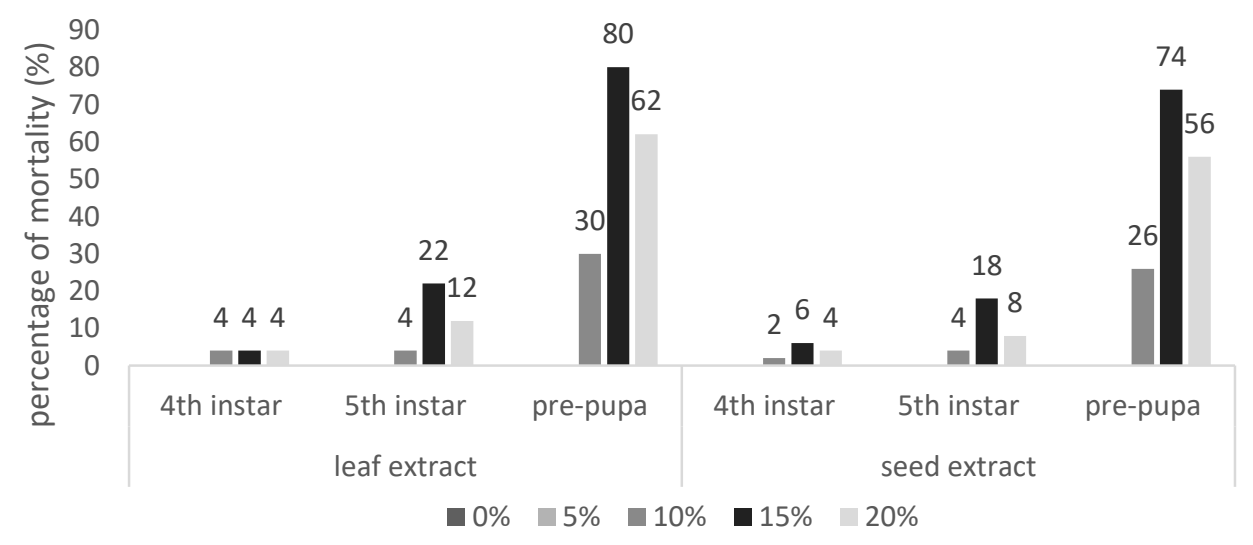

Figure 5. Percentage mortality of S. litura diet by moringa leaf and seed extract

Mortality began in 4 th instar diet by $0 \%, 15 \%$, and $20 \%$ concentration of extract (Fig. 5). The highest mortality occurred in $15 \%$ extract in prepupa phase. Mortality caused by quality and quantity of diet on stage larvae. The secondary metabolites in both extracts are toxic and the toxicity in larvae also increase due to feeding activities, the larvae were unable to neutralize toxins in the body. These toxic reduce metabolic activity resulting in mortality. The insect that is exposed to insecticides in lethal concentrations affected the physiological and behavioral changes, resulting in stunted growth and failure in pupae formation [31].

\section{CONCLUSION}

The treatment of leaf extract and Moringa seeds affect the length shringkage, lose weight of S. litura larvae. Both extracts also caused longer larval development in instar growth but reduce food intake. The number of larvae that consume feed that has been given extract also decreases with every increase in time. This antifeedant effect gives mortality to the larvae. 


\section{ACKNOWLEDGEMENT}

The authors are thankful to $\mathrm{Mr}$ Sukir in BALITTAS for supply the $S$. litura.

\section{REFERENCES}

[1] Hadi, M., Aminah. 2012. Keragaman serangga dan perannya di ekosistem sawah (Insect diversity and its role in weatland ecosystem). Jurnal Sains dan Matematika. 20(3). 54-57.

[2] Elleuch, J., R.Z. Zghal, M. Jemaa, H. Azzouz, S. Tounsi, S. Jaoua. 2014. New Bacillus thuringiensis toxin combination for biological control of Lepidopteran Larvae. International J. Biol. Macromol. 65. 148-154.

[3] Tengkano, W., Suharsono. 2005. Ulat Grayak Spodoptera litura Fabricius (LEPIDOPTERA: NOCTUIDAE) pada tanaman kedelai dan pengendaliannya. Buletin Palawija. 10. 43-52.

[4] Badathu, M., V. Lingampally, A. Kaur. 2014. Effect of betulinic acid on Spodoptera litura (Fab.) (Lepidoptera: Noctuidae). Indian J. Sci. Res. 8(1). 177-181.

[5] Kandagal, A., M.C. Khetagoudar. 2013. Study on larvacidal activity of weed extracts against Spodoptera litura. J. Environ. Biol. 34. 253-257.

[6] Yanuwiadi, B., A.S. Leksono, H. Guruh, M. Fathoni, Bedjo. 2013. Potensi ekstrak daun sirsak, biji sirsak, dan biji mahoni untuk pengendalian ulat Grayak (Spodoptera litura L.). Natural B. 2(1). 88-93.

[7] Sa'diyah, N.A., K.I. Purwani, L. Wijayawati. 2013. Pengaruh ekstrak daun Bintaro (Carbera odollam) terhadap perkembangan ulat Grayak (Spodoptera litura F.). Jurnal Sains dan Seni Pomits. 2(2). E111-E115.

[8] Aliyu, A., U.D. Chukwuna, E.H. Omoregie, K.O. Folashade. 2016. Qualitative phytochemical analysis of the leaf of Moringa oleifera lam. from three climatic zones of Nigeria. J. Chem. Pharm. Res. 8(8). 93-101.

[9] Prabhu, K., K. Murugan, A. Nareshkumar, N. Ramasubramanian, S. Bragadeeswaran. 2011. Larvacidan and repellent potential of Moringa oleifera against malaria vector, Anopheles stephensi Liston (Insecta: Diptera: Culicidae). Asian Pac. J. Trop. Biomed. 124-129.

[10] Pontual, E.V., T.H. Napoleao, C.R.D. Assis. R.D.S Bezzerra, H.S. Xavier, D. Navarro, L.C. Coelho, P.M.G. Paiva. 2012. Effect of Moringa oleifera flower extract on larval trypsin and acetylcholinesterase activity in Aedes aegypti. Arch. Insect Biochem. Physiol. 79(3). 135-152.

[11] Anas, Y., A. Imron, S.I. Ningtyas. 2016. Ekstrak daun kelor (Moringa oleifera Lam.) sebagai peluruh kalsium batu ginjal secara In Vitro. Jurnal Ilmu Farmasi dan Farmasi Klinik. 13(2). 7-15.

[12] Chauhan, D., V.K. Mishra. 2016. Effect of medicinal plant extract on growth and development of Tobacco Caterpillar, Spodoptera litura (Fabricius). Int. J. Agr. Environ. Biotech. 9(3).435-442.

[13] Wardani, E., H. Sunaryo, M.Z. Sopiani, M. Fatahillah. 2015. The antihypertriglyceride activity and antihyperglycemic of ethanol extract of Moringa leaves (Moringa oleifera Lam.) on hypertriglyceride diabetes rats. Media Farmasi. 22(2). 199-212.

[14] Ezeigbo, I.C., O.R. Ezeigbo. 2016. Phytochemical and nutritional evaluation of southeastern Nigerian grown Moringa oleifera leaf extract. J. Complement. Altern. Med. Res. 1(4). 1-8.

[15] Belete, T. 2018. Defense mechanisms of plants to insect pests: from morphological to biochemical approach. Trends Technic. Sci. Res. 2(2). 001-009

[16] Matsuura, H.N., A.G. Neto. 2015. Plant alkaloids: main features toxicity, and mechanism of action. Plant Toxins Springer Science. 1-15.

[17] Acheuk, F., B.D. Mitiche. 2013. Insecticidal activity of alkaloids extract of Pergularia tomentosa (Asclepiadaceae) against fifth instar larvae of Locusta migratoria cinerasces (Fabrisius 1781) (Orthoptera: Acrididae). Int. J. Sci. Adv. Technol. 6(3). 813

[18] Abbassi, K., Z.A. Kadiri, S. Ghaout. 2003. Biological effects of alkaloids extracted from three plants of Moroccan areas on the Desert Locust. Physiol. Entomol. 28. 232236.

[19] Aniszewski, T. 2007. Alkaloids- secrets of life. Alkoloid chemistry, biological significance, applications and ecological role. Elsevier. Amsterdam. 185-186.

[20] Ahdiyah, I., K.I. Purwani. 2015. Pengaruh ekstrak daun mangkokan (Nothopanax scutellarium) sebagai larvasida nyamuk Culex sp. Jurnal Sains dan Seni ITS. 4(2). 3236. 
[21] Boue, S.M., S.K. Raina. 2003. Effects of plants flavonoids on fecundity, survival, and feeding of the formosan subterranean termite. J. Chem. Ecol. 29(11). 2575-2584.

[22] Mierziak, J., K. Kostyn, A. Kulma. 2014. Flavonoids as important molecules of plants interactions with the environment. Molecules. 19. 16240-16265.

[23] Chowanski, S., Z. Adamski, P. Marciniak, G. Rosinski, E. Buyukguzel, K. Buyukguzel, F. Patrizia, L. Scrano, E. Ventrella, F. Lelario, S.A. Bufo. 2016. Review: a review of bioinsecticidal activity of Solanaceae alkaloids. Toxins. 8(60). 1-28.

[24] Hasnah, Husni, A. Fardhisa. 2012. Effect of rhizome extract of sweet flag (Acorus calamus L.) on mortality of grayak caterpillar Spodoptera litura. J. Floratek. 7. 115-124.

[25] Aminah, N.S.S., S. Sigit, Partosoedjono, Chairul. 2001. S. lerak, D. metel, dan E. prostata sebagai larvasida Aedes aegypti. Cermin Dunia Kedokteran. 131. 7-9.

[26] Chaieb, I. 2010. Saponins as insecticides: a review. Tunis. J. Plant Prot. 5. 39-50.

[27] Khairul, A.U., C. Vemithasa. 2018. The Potential of Vitex trifolia (Verbenaceae) as a botanical insecticide to control Crocidolomia pavonana (Lepidoptera: Crambidae). Proceeding of Nasional Seminar of Indonesian Biodiversity Community. 4(2). 169-170.

[28] Lukman, A. 2009. Hormon role in insect methamorphosis. Biospecies. 2(1). 42-45.

[29] Chinelo, A., C.U. Okeke, O. Bibian, V. Cinyere, A. Emeka. 2014. Determination of saponin content of various Parts of six citrus species. Int. Res. J. Pure Appl. Chem. 4(1). 137-143.

[30] Tambe, V.D., R.S. Bhambar. 2014 Estimation of total phenol, tannin, alkaloid, and flavonoid in Hibiscus tiliaceus Linn. wood extract. Res. Rev. J. Pharmacog. Phytochem. 2(4). 41-47.

[31] Muta'ali, R., K.I. Purwani. 2015. Pengaruh ekstrak daun beluntas (Pluchea indica) terhadap mortalitas dan perkembangan larva Spodoptera litura F. Jurnal Sains dan Seni ITS. 4(2). E55-E58. 